J. Perinat. Med. $10(1982) 48$

\section{Neonatal effects of the administration of meperidine and promethazine to the mother in labor. Double blind study}

\author{
M. Busacca*, P. Gementi*, E. Gambini**, C. Lenti**, F. Meschi***, M. Vignali* \\ * $5^{0}$ Clinic of Obstetric and Gynecology University of Milan, \\ L. Sacco Hospital, Milan \\ ** Institute of Children's Neuropsychiatry, University of Milan \\ *** $3^{0}$ Clinic of Pediatrics, University of Milan, L. Sacco Hospital, Milan
}

\section{Introduction}

The use of meperidine in obstetrical analgesia and its limits have been studied above all in connection with the most common neonatal data $[1,7,14$, 19]. EsCARdo DE Coriat's researches in 1966 pointed out for the first time an impairment of responsiveness to stimuli in babies born to mothers premedicated with analgetics in labor, particularly with meperidine.

A deeper evaluation of these aspects of the neonatal status was made by BRAzELTON who, using his own neurobehavioral scale, described similar observations in 1973 [5] and confirmed them in 1977 [6].

Borgstedt [3] came to the same conclusions using the techniques of BRECHTL-BEINTEMA at 36 and 72 hours from birth. BRACKBILL [4] demonstrated that only some behavioral parameters of the infants were altered at birth in newborns exposed to meperidine (interest in voice, defence, consolability and so on).

When new experiments were made with different neurobehavioral and attitudinal tests (SCANLON test) and different stimuli $[8,15,17]$, remarkable differences were always noticed between groups of babies exposed to meperidine and not exposed ones.

After the result of the previous researches we thought it useful to verify the effects of the association of meperidine and promethazine on the

\section{Curriculum vitae}

MAURO BUSACCA was born in 1949, Milan, Italy. He took his degree in Medicine and Surgery in 1974 at Milan University. He specialized in Obstetrics and Gynecology in 1978. Since 1975 he has been working as University Assistant in the Department of Obstetrics and Gynecology of L. Sacco Hospital in Milan. He is principally interested in perinatal medicine and pregnancy pathology. He has made several stages in various departments of High Risk Pregnancy in Europe. A number of studies about the subject matter of his main interests have already been or are being published.

behavior of the newborn in order to estimate the actual possibility of using such method.

\section{Method and material}

The cases were gathered in the period between September 1979 and May 1980. Sixty mothers in labor and their babies were taken into consideration and they were divided into two randomized groups, $\mathrm{A}$ and $\mathrm{B}$, with particular homogeneous characteristics (Tab. I).

Thirty women of the A group were premedicated in labor with one i.v. injection of meperidine 
Tab. 1. Characteristics of the population in study.

\begin{tabular}{|c|c|c|c|c|}
\hline & \multicolumn{2}{|l|}{ Mothers } & \multicolumn{2}{|c|}{ Newborns } \\
\hline & $\begin{array}{l}\text { Average } \\
\text { age } \\
\text { (years) }\end{array}$ & $\begin{array}{l}\text { Parity } \\
01-23\end{array}$ & $\begin{array}{l}\text { Gest. } \\
\text { age } \\
\text { (weeks }\end{array}$ & $\begin{array}{l}\text { Weight } \\
\text { gr. }\end{array}$ \\
\hline Meper. prom. & $\begin{array}{c}28.07 \\
\pm 5.29\end{array}$ & 20100 & 39.8 & $\begin{array}{r}3339.17 \\
\pm 432.95\end{array}$ \\
\hline No treatment & $\begin{array}{l}26.80 \\
\pm 4.60\end{array}$ & 16113 & 39.6 & $\begin{array}{r}3285.83 \\
\pm 309.3\end{array}$ \\
\hline
\end{tabular}

$50 \mathrm{mg}$ and promethazine $25 \mathrm{mg}$. A $2-4 \mathrm{~cm}$ dilatation with presenting head was chosen as administration time.

The B group, composed of the same number of women, were not given any analgetic treatment in labor.

Either the women had a biophysical monitoring with U.S. or an electrode had been put on the fetal scalp throughout the labor. All the newborns were given an APGAR score at 1 and 5 minutes of birth. All the data concerning the status of these babies in their early neonatal period (5-7 days) were also registered. Twin pregnancies and dystocic deliveries (by vacuum extractor, forceps, breech presentation or cesarean section) were excluded from the cases or not taken into consideration as well as women who had been premedicated in labor with different analgetic and/or anesthetic drugs, or who had taken psychodrugs within seven days from the beginning of the labor. We finally excluded premature babies (less than 37 weeks) and the mothers who had developed any pathology in pregnancy.

The neurobehavioral assessment was made in double blind. For this evaluation we used BRAZELTON's scale considering the most significant tests. The test was made within $24-48$ hours of birth, during the feeding intervals, in a quiet faintlylit room, at a temperature of 22-26 C., with babies in cradles, asleep, clothed and covered. The result of each test made in the two samples of babies were later evaluated through a chi square test. Finally we studied the correlation between the baby's behavior and the time between the administration of meperidine and promethazine and delivery.

\section{Results}

3.1 APGAR score and early neonatal morbidity: The data quoted in Tab. II do not indicate any difference between the values of the APGAR score in the two groups both after 1 and 5 minutes of birth. Also the clinical assessment of the newborns, expressed in average days of stay in hospital, does not show any remarkable difference between babies exposed to meperidine and promethazine and non-exposed ones.

Tab. II. Perinatal state indices.

\begin{tabular}{llllll}
\hline & APGAR 1' & APGAR 5' & $\begin{array}{l}\text { Days } \\
\text { of stay } \\
\text { in hos- } \\
\text { pital }\end{array}$ \\
\hline $\begin{array}{l}\text { Meper. } \\
\text { prometh. }\end{array}$ & 0 & $\begin{array}{l}30 \\
(100 \%)\end{array}$ & 0 & $\begin{array}{l}30 \\
(100 \%)\end{array}$ & 5.3 \\
$\begin{array}{l}\text { No } \\
\text { treatment }\end{array}$ & 0 & $\begin{array}{l}30 \\
(100 \%)\end{array}$ & 0 & $\begin{array}{l}30 \\
(100 \%)\end{array}$ & 5.0 \\
\hline
\end{tabular}

3.2 Neurobehavior: The differences between the two groups of infants that resulted statistically significant according to the scale of BRAzELTON were those concerning the hand-to-mouth activity, the plantar reflex and the general body tone considered according to various methods (ventral suspension, passive movements, traction). The modifications of the experimental group in comparison with the control group clearly showed a reduction. The other tests, which instead demonstrated slight variations, remained within confidence limits (Tab. III). On the contrary it was not possible to notice any relationship between the alterations of the tests and the time between treatment and delivery or the moment of the neurologic test: The presence of slightly insufficient tests does not seem to depend upon the time of intrauterine permanence (Tab. IV).

\section{Comments.}

The several data in literature concerning the action of the association of meperidine and promethazine would force us to exclude noxious effects on the mother, in the dosage used in 
Tab. III. Response to BRAZELTON's test in the newborns exposed to meperidine and promethazine and in the controls. The number of newborns having a response to the test different from the best performance is expressed in percentage.

\begin{tabular}{lll}
\hline Test & $\begin{array}{l}\text { Meper. } \\
\text { prom. }\end{array}$ & $\begin{array}{l}\text { Non } \mathrm{p} \\
\text { treated }\end{array}$ \\
\hline
\end{tabular}

\section{Reflexes}

\begin{tabular}{|c|c|c|c|}
\hline Plantar grasp & 26 & 7 & 0.001 \\
\hline Palmar grasp & 23 & 17 & N. S. \\
\hline Ankle clonus & 20 & 30 & N. S. \\
\hline Babinsky & 7 & 10 & N. S. \\
\hline Authomatic walk & 47 & 57 & N.S. \\
\hline Placing & 23 & 23 & N. S. \\
\hline Cardinal points & 40 & 30 & N.S. \\
\hline Sucking & 27 & 30 & N. S. \\
\hline Glabella & 7 & 7 & N. S. \\
\hline Tonic neck reflex & 40 & 37 & N. S. \\
\hline Moro reflex & 27 & 27 & N. S. \\
\hline \multicolumn{4}{|l|}{ Tone } \\
\hline Tone in ventral suspension & 33 & 16 & 0.01 \\
\hline Tone in passive movement & 30 & 7 & 0.001 \\
\hline General tone & 47 & 27 & 0.001 \\
\hline Traction & 40 & 20 & 0.001 \\
\hline \multicolumn{4}{|l|}{ Behaviour } \\
\hline To light & 50 & 50 & N.S. \\
\hline To sound & 17 & 23 & N. S. \\
\hline To pinprick & 77 & 87 & N. S. \\
\hline Inanimate visual stimulus & 70 & 67 & N. S. \\
\hline Global motorial maturity & 20 & 10 & N. S. \\
\hline Cuddling & 27 & 27 & N.S. \\
\hline Defense & 60 & 70 & N. S. \\
\hline Consolability & 3 & 3 & N. S. \\
\hline Build-up & 23 & 13 & N.S. \\
\hline State lability & 90 & 80 & N. S. \\
\hline Skin colour labil. & 3 & 0 & N. S. \\
\hline \multicolumn{4}{|l|}{ Spontaneous and } \\
\hline provoked activity & 70 & 60 & N. S. \\
\hline Tremors & 10 & 7 & N. S. \\
\hline Startles & 3 & 7 & N. S. \\
\hline Hand-to-mouth activity & 70 & 50 & 0.001 \\
\hline
\end{tabular}

Tab. IV. Evaluation of the course of the test presenting statistically significant deviations expressed as a function of the time between the administration of meperidine and prometazine and the examination.

\begin{tabular}{|c|c|c|c|c|}
\hline $\begin{array}{l}\text { Time } \\
\text { administration- } \\
\text { test }\end{array}$ & $\begin{array}{l}\text { New- } \\
\text { born } \\
\text { tested }\end{array}$ & $\begin{array}{l}\text { Newborns } \\
\text { with all } \\
\text { optimal } \\
\text { perform- } \\
\text { ances }\end{array}$ & $\begin{array}{l}\text { Newborns } \\
\text { with } 1 \text { or } 2 \\
\text { altered } \\
\text { perform- } \\
\text { ances }\end{array}$ & $\begin{array}{l}\text { Newborns } \\
\text { with more } \\
\text { than } 2 \\
\text { alterated } \\
\text { perform- } \\
\text { ances }\end{array}$ \\
\hline $\begin{array}{l}\leqslant 24 \text { hours } \\
25-48 \text { hours } \\
>48 \text { hours }\end{array}$ & $\begin{array}{r}5 \\
18 \\
7\end{array}$ & $\begin{array}{ll}0 & (0 \%) \\
4 & (22 \%) \\
2 & (29 \%)\end{array}$ & $\begin{array}{ll}1 & (20 \%) \\
9 & (50 \%) \\
2 & (29 \%)\end{array}$ & $\begin{array}{ll}4 & (80 \%) \\
5 & (28 \%) \\
3 & (42 \%)\end{array}$ \\
\hline
\end{tabular}

obstetrics; on the contraty it would help a quicker delivery.

The results about the neonatal status are more discussed; in particular they seem to depend on the dosage and the method of administration. As for this subject, it is well established that the most common parameters (APGAR - acid base balance) are not modified by the meperidine used in labor. It is right to think that the most complex functions of the newborn are not completely reflected in the evaluation of the above-quoted indices. In fact we can put forward the hypothesis that, thanks to the relative permeability of the hematoencephalic barrier, there should be a deposit of the substances employed at the cortical level, without any interaction with the bulbar centres (respiratory and cardiocirculatory). The use of neuro-attitudinal and psychophysiological tests in the newborns has demonstrated modifications of some neurobehavioral status overall in connection with the dosage of meperidine employed.

The comparison of our data with those of other authors allows us to underline some important differences. The significant reduction of the general body tone and of the plantar grasp had already been pointed out by BRAZELTON, BRACKBILL and HoDGKINSON: Moreover these authors noticed a reduction in the responsiveness to sound stimuli $[4,5,9]$. The comparison between the two groups of our subjects does not point out all these differences: Only the hand-to-mouth test shows a reduced reactivity.

On the other hand these tests have shown that only the functions depending on anatomofunctional structures phylogenically and ontogenetically more archaic (cerebral trunk and cerebellum) seem to be altered, while -the functions connected with more specialized and complex neurophysiological mechanisms (in any case connected with the possibility of environmental interactions) are unvaried.

Another point of the problem where we disagree with other authors is the impossibility to demonstrate with our data an interaction between the moment of the administration in labor and the incidence or the seriousness of the effects on the newborn. To justify these differences it is necessary to consider the importance of the drug dosage and 
the way of administration: Almost in all previous neurobehavioral studies the dosage of meperidine is varying from 50 to $150 \mathrm{mg}$, very seldom associated with promethazine and, in any case, always by intramuscular injection. The use of promethazine has permitted us to keep the therapeutic levels of meperidine at $50 \mathrm{mg}$, a dose free from any fetal and maternal risk $[11,16]$; moreover the moment chosen for administration very seldom requires a repetition of it.

I.v. injection, because of the quick passage into the fetal circulation reduces the presence of the catabolites of meperine to the least; in particular normoperidine is produced by the liver from the degradation of the original substance. Since the fetal liver does not own the necessary enzymes, it is plain that this degradation depends on the mother's liver and therefore on the possibility of a long persistence of the drug in the mother's blood, which is obtained by intramuscular administration.

\section{Summary}

The authors have verified the possible neonatal effects of the administration of meperidine and promethazine in labor, principally in connection with the neurobehavior of the newborn babies in the first hours of life. For this verification we have employed the technique proposed by BRAZELTON, using the tests considered as the most meaningful by the international literature. We have also examined a homogeneous group of babies as a control group for possible changes. The tests were made in double blind and always by the same tester.

The APGAR score and the early neonatal morbidity, evaluated in days of stay in hospital, did not give any significant statistic results in the two groups.

Also some neurobehavioral tests appeared more frequently altered in statistically significant terms according

Keywords: Analgesia in labor, meperidine, promethazine.
Even if the question is not confirmed by everybody, we have received various reports about a greater toxic action of normoperidine and of the normoperidinic acid in comparison with the original substance $[12,13]$. This would justify the reduced responsiveness to stimuli reported by some but not confirmed by us.

The data of these studies inevitably rise a question: What is the duration of premedication effects and what are the ultimate effects on the baby?

Because of the absence of difference between our results after 24 and 48 hours of birth, we should deduce that the disappearance of meperidine from the cerebral receptorial situs is not very quick. In fact a previous research put forward the hypothesis that the effects of this drug would last about four weeks; the result seems rather important also for the possible consequences for the baby and it needs further confirmation since the results we have obtained do not allow us to make sure deductions about this point.

to the scale proposed by BRAZELTON. The tests which showed these changes (in the sense of a deviation from the best performance) were those concerning the handto-mouth activity $(p<0.001)$, the plantar reflex $(p<0.001)$ and the general body tone evaluated with different parameters (ventral suspension: $p<0.01$; passive movements: $p<0.001$; traction: $p<0.001$ ).

The other tests, which showed instead slight variations, remained in the confidence limits (Tab. III).

It was not possible to notice any interaction between the alteration of the tests and the time between the administration and delivery or the moment of the neurologic test: The presence of slightly insufficient tests does not seem to be connected with the time of intrauterine permanence.

\section{Zusammenfassung}

Doppelblindstudie tiber die Auswirkungen der Meperidine- und Promethazine-Gabe an die Mütter während der Entbindung auf die Neugeborenen

Das neurologische Verhalten in den ersten Lebensstunden von Neugeborenen, deren Mütter Meperidine und Promethazine während der Geburt bekommen hatten, wurde untersucht.
Für den Zweck wurde die Methode von BRAZELTON genommen.

Die Testbatterie wurde entsprechend der internationalen Literatur zusammengestellt. Eine homogene Vergleichsgruppe wurde mit den gleichen Tests im Doppelblind-Verfahren von der gleichen Testperson untersucht. Der APGAR-Wert und die neonatale Morbidität (ausge- 
drückt in Tagen Krankenhausaufenthalt) ergaben keinen signifikanten Unterschied in den zwei Gruppen. Nach der BRAZELTON Skala gab es bei mehreren neurologischen Tests einen signifikanten Unterschied.

Diese Tests waren: 1. Hand $\mathrm{zu}$ Mund Bewegung $(P<0,001)$, 2. Plantarreflex $(P<0,001)$, 3. Allgemeiner Körpertonus gemessen mit verschiedenen Parametern (Bauchlage: $\mathrm{P}<0,01$; passive Bewegung: $\mathrm{P}<0,001$; Traktion: $\mathrm{P}<0,001)$.
Die anderen Untersuchungen, die nur leichte Abweichungen aufwiesen, blieben noch im Vertrauensbereich. (Tab. III). Zeitpunkt der Untersuchung und Zeitraum zwischen Verabreichung und Geburt konnten die Testergebnisse nicht beeinflussen.

Die Anwesenheit von leicht unzureichenden Tests konnten nicht durch die intra-uterine Verweildauer erklärt werden.

Schlüsselwörter: Analgesie während der Geburt, Meperidine, Promethazine.

\section{Résumé}

L'effet néonatal suite à l'administration à la mère pendant l'accouchement de Meperidine et de Promethazine. Etude à double aveugle.

Les auteurs ont vérifié l'effet néonatal de l'administration de meperidine et de promethazine pendant l'accouchement de la mère, principalement le comfortement neurologique des nouveau - nés durant les premières heures de leur vie. Pour cette étude nous avons utilisé la technique proposée par BRAZELTON en utilisant les tests considérés comme les plus aptes par la literature internationale. Un groupe homogène de contrôle fût examiné par le même opérateur selon le principe de double aveugle. Le score APGAR et la morbidité néonatale (exprimé en jours d'hospitalisation) n'a pas donné de différence significative dans les deux groupes. D'après l'échelle de BRAZELTON il y avait quelques tests neurologiques présentant une différence significative. Ces tests étaient: 1 . le mouvement de la main à la bouche. $(p<0,01), 2$. le reflex plantaire $(p<0,001)$, 3. le tonus corporel général mesuré avec des paramètres différents (couché sur le ventre; $p<0,01$; mouvements passifs: $\mathrm{p}<0,001$ traction: $\mathrm{p}<0,001$ ).

Les autres tests qui ne présentaient que de légères variations restaient cependant dans la limite de confiance (Tab. III). Le moment de l'examen, le délai entre l'administration et l'accouchement n'avaient pas d'influence sur le test.

La présence de tests légèrement insuffisants ne semblaient pas être expliquée par la durée de la rémanence intrauterine.

Mots-clés: Analgésie pendant l'accouchement, meperidine, promethazine.

\section{Bibliography}

[1] Adelman, H., E. JACobSon, P. A. LIEF: Prometazine hydrochloride in surgery and obstetrics. J.A.M.A. 169 (1959) 73

[2] BONTA, B. W., J. V. GAGLIARDI, V. WILliAMS, J. B. WARSHAW: Naloxone reversal of mild neurobehavioral depression in normal newborn infant after routine obstetric analgesia. J. Pediat. 94 (1979) 102

[3] BORGSTEDT, A. D., M. G. ROSEN: Medication during labor correlated with behavior and EEG of the newborn. Amer. J. Dis. Child. 115 (1968) 21

[4] BRACKBILL, Y., J. KANE, R. L. MANNIELlO, D. ABRAMSON: Obstetric premedication and infant outcome. Amer. J. Obstet. Gynec. 118 (1974) 377

[5] BRAZELTON, T. B.: Neonatal behavioral assessment scale. Clin. Dev. Med. 50 (1973) 1

[6] BRAZELTON, T. B.: Scala per la valutazione del comportamento del neonato. Ed. Ambrosiana, Milano 1977

[7] CARROLL, J. J., R. S. MOIR: Úse of prometazine (phenergan) hydrocloride in obstetrics. J.A.M.A. 168 (1958) 2218

[8] FANTZ, R. L.: Pattern vision in newborn infant. Science 140 (1963) 296
[9] HODGKINSON, R., M. BHATT, C. N. WANG: Double-blind comparison of the neurobehaviour of neonates following the administration of different doses of meperidine to the mother. Canad. Anaesth. Soc. J. 25 (1978) 405

[10] KLAUS, M. H., H. C. JERAULD, W. KREGER, M. MCALPINE, J. STEFF, H. KENNELL: Maternal attachment. Importance of the first post-partum days. N. Engl. Med. 286 (1972) 460

[11] KLIGER, B., H. B. NELSON: Analgesia and fetal depression with intravenous meperidine and propiomazine. Amer. J. Obstet. Gynec. 92 (1965) 850

[12] MORRISON, J. C., W. L. WISER, S. I. ROSSER, J. O. GAYDEN, E. T. BUCOVAR, W. D. WHYBREW, S. A. FISH: Metabolites of meperidine related to fetal depression. Amer. J. Obstet. Gynec. 115 (1973) 1132

[13] MORRISON, J. C., W. D. WHYBREW, S. I. ROSSER, E. T. BUCOVAR, W. L. WISER, S. A. FISH: Metabolites of meperidine in the fetal and maternal serum. Amer. J. Obstet. Gynec. 126 (1976) 997

[14] POTTS, C. R., J. C. ULLERY: Maternal and fetal effects of obstetrics analgesia. Amer. J. Obstet. Gynec. 81 (1961) 1253 
[15] SCANLON, J. W., W. U. BROWN, J. B. WEISS, H. M. ALPER: Neurobehavioral responses of newborn infants after maternal epidural anaesthesia. Anesthesiology 40 (1974) 121

[16] SCHNIDER, S. M., F. MOYA: Effects of meperidine on the newborn infant. Amer. J. Obstet. Gynec. 89 (1964) 1009

[17] STECHKER, G.: Newborn attention as affected by medication during labor. Science 144 (1964) 315
[18] TURNER, S., A. MCFARLANE: Localisation of human speech by the newborn baby and the effects of Pethidine (Meperidine). Develop. Med. Child. Neurol. 20 (1978) 727

[19] Vignali, M., M. BUSACCA, E. Bosisio, G. MOTTA: Il parto in analgesia: l'associazione meperidina-prometazina. Ann. Ost. Gin. Med. Perin. 4 (1977) 252

Received April 29, 1981. Accepted August 4, 1981.

Dr. Mauro Busacca

Via Ressi A., 32

I-20125 Milano 